\title{
Physical activity as a component of a healthy lifestyle
}

\author{
Olga Sokolova*, Nadezhda Goncharova, Valentina Lapina, and Alexander Goncharov \\ Ural State University of Economics, 620144 Yekaterinburg, Russia
}

\begin{abstract}
The article provides definitions of the following concepts: health, healthy lifestyle and physical activity. The article lists some of the principles that influence the human condition (external and internal). The main topic of the article is physical activity as one of the most important elements of a healthy lifestyle. A sociological survey was conducted in online and offline formats to identify the preferences of the population of different ages in the field of sports culture. During the analysis of the results of this study, problematic points were found and recommendations were given for maintaining and improving health through physical activity. The positive and negative aspects of the four most popular training options are reviewed and identified. The article mentions modern devices, applications and programs that motivate people to exercise and help track results. In addition, they noted the interest of the state in a healthy population, and also named some of the government's actions for the development of physical culture in the country. At the end of the article, the main results of the survey are briefly highlighted. The conclusion was made about the need for correct goal setting, search for suitable activity and motivation.
\end{abstract}

\section{Introduction}

A healthy lifestyle is a system of behavior aimed at improving and maintaining health. We can say that this is a way of life in which you think about yourself not only in the present, but also in the future. Many scientists paid close attention to the problems of a healthy lifestyle [1-14]. Nowadays attention should be paid to another question - what is health. As defined by the World Health Organization, human health is a state of complete physical, spiritual and social well-being, and not just the absence of disease or physical defects [15]. A healthy lifestyle is a complex of different measures and consists of many aspects. The most famous components of this system are proper nutrition, hygiene, avoiding bad habits, physical activity and adequate sleep.

From this set, we will concentrate on physical activity. From the definition of the World Health Organization, we can learn that physical activity is any movement of the body produced by skeletal muscle that requires energy expenditure, including activity during work, play, homework, travel, and recreational activities. It is important to understand that professional sports are fundamentally different from the concept of sports in a healthy lifestyle. Professional sports are primarily aimed at achieving results, therefore they are often

\footnotetext{
*Corresponding author: olgalsokol@mail.ru
} 
harmful to health. Therefore, in the future, under the word "sport" we mean physical activity aimed at preventing disease and strengthening the body.

\section{Research materials and methods}

In the course of work on the article, a survey was conducted in order to investigate the sports preferences of society, as well as the reasons that interfere with an active lifestyle. The survey involved people from different age groups (from schoolchildren to people of retirement age). The survey was conducted online (Google-form) and offline (survey of passers-by). The survey consisted of 13 closed-ended questions, in 3 of which several options could be selected.

As a result of the survey, it was found that almost $70 \%$ of the respondents lead an active lifestyle. However, many found it difficult to answer the question of at what age the understanding of the importance of physical activity came.

\section{Results and discussion}

There is a new trend in the modern world - a healthy lifestyle. Gyms and health food stores are gaining popularity. More and more often you can hear talk about the importance of a balanced diet and avoiding sugar, more and more often you can see people who play sports on the street, ride bicycles or play some kind of outdoor games (football, volleyball, basketball, etc.). However, it must be recognized that the markets for tobacco and alcoholic products also do not experience a shortage of consumers. And yet, one way or another, people come to understand that health is the main wealth of a person. They say that time is an irreplaceable resource. Then what about health? It is a blessing that cannot be acquired. Maintaining and strengthening health is work. And it is this work that is the best investment in the future. Figure 1 shows that people prefer to exercise at home or in the gym. However, it should be noted that during the coronavirus pandemic, outdoor training was actively carried out, as access to fitness clubs was limited. Some fitness trainers began to conduct their classes outside the gym, which allowed more people to start training without having to pay for a membership to the club. People took their own sports equipment with them (training mats, expanders, etc.), and also used the possibilities of various sports grounds.

\section{Where do you play sports?}

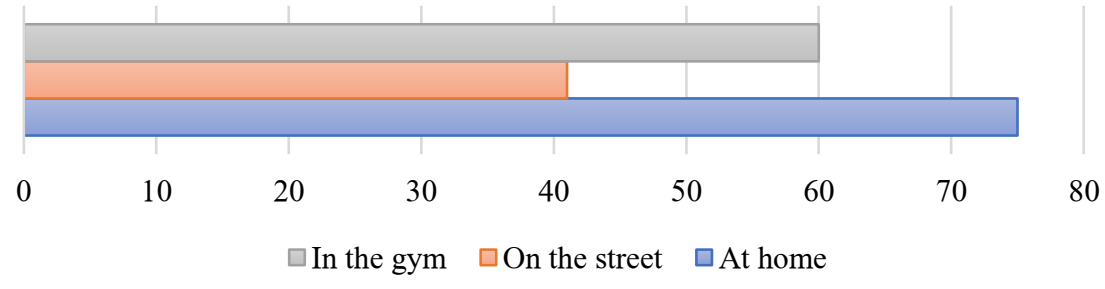

Fig. 1. Where do you play sports?

An interesting point is that more than half $(54.6 \%)$ ignore exercise in the morning. This is due to the lack of a clear sleep schedule and the desire to sleep longer. And it is very in vain, since charging has many advantages:

- Prevention of many diseases;

- Strengthening the heart muscle; 
- Improvement and activation of the brain by saturating it with oxygen;

- Cheerfulness;

- Improvement of physical activity and muscle strengthening;

- Good mood, etc.

The next question that we drew attention to is how exactly people prefer to go in for sports: independently, under the supervision of a coach, in the format of group training or in the company of friends. Table 1 shows the proposed options.

Table 1. Signs of tax regimes that have the potential to develop unfair tax competition.

\begin{tabular}{|c|c|c|}
\hline Option & Benefits & Disadvantages \\
\hline $\begin{array}{l}\text { On one's } \\
\text { own }\end{array}$ & $\begin{array}{l}\text { 1) You can practice anytime and } \\
\text { anywhere (house, street, gym); } \\
\text { 2) The ability to independently create } \\
\text { a training program; } \\
\text { 3) The ability to work out only the } \\
\text { muscles you need; } \\
\text { 4) Cost savings when compared to } \\
\text { personal training. }\end{array}$ & $\begin{array}{l}\text { 1) Motivation is somewhat lower due to } \\
\text { the lack of a clear time and people waiting } \\
\text { for you. That is, there is a temptation to } \\
\text { skip a workout, or even all } 10 \text {; } \\
\text { 2) The ability to harm yourself due to a } \\
\text { lack of knowledge and improper exercise } \\
\text { technique. }\end{array}$ \\
\hline $\begin{array}{l}\text { Supervised } \\
\text { by a trainer } \\
\text { (personal } \\
\text { training) }\end{array}$ & $\begin{array}{l}\text { 1) A professional makes the necessary } \\
\text { training program, guided by your } \\
\text { goals and wishes; } \\
\text { 2) Control over the correct execution } \\
\text { of exercises; } \\
\text { 3) Motivation. It works from several } \\
\text { sides: to recoup the economic costs, } \\
\text { the need to come to training, as they } \\
\text { are waiting for you; } \\
\text { 4) Opportunity to ask a question to a } \\
\text { professional, get advice. }\end{array}$ & $\begin{array}{l}\text { 1) Expensive enough; } \\
\text { 2) The need to take into account not only } \\
\text { your schedule, but also the coach's } \\
\text { schedule; } \\
\text { 3) The risk of getting to an incompetent } \\
\text { coach. }\end{array}$ \\
\hline $\begin{array}{l}\text { Group } \\
\text { training }\end{array}$ & $\begin{array}{l}\text { 1) A competitive process that } \\
\text { encourages you to work harder; } \\
\text { 2) The ability to communicate with } \\
\text { like-minded people; } \\
\text { 3) The coach controls the correct } \\
\text { execution of the exercises; } \\
\text { 4) An atmosphere that sets you up for } \\
\text { productive work. }\end{array}$ & $\begin{array}{l}\text { 1) Embarrassment and embarrassment in } \\
\text { front of strangers; } \\
\text { 2) The need to follow the schedule of the } \\
\text { club. If with personal training it is possible } \\
\text { to agree on the time, then with group } \\
\text { training it is not; } \\
\text { 3) Individual characteristics and whole are } \\
\text { not taken into account; } \\
\text { 4) The absence of strict restrictions on the } \\
\text { number of people, i.e. the number of } \\
\text { people in the gym can exceed the number } \\
\text { at which it is comfortable to practice. }\end{array}$ \\
\hline In company & $\begin{array}{l}\text { 1) Opportunity to spend time with } \\
\text { friends / family; } \\
\text { 2) More fun and more interesting than } \\
\text { independent studies; } \\
\text { 3) Support from loved ones; } \\
\text { 4) Ability to independently draw up a } \\
\text { training plan and regulate the degree } \\
\text { of load; } \\
\text { 5) Competitive moment. }\end{array}$ & $\begin{array}{l}\text { 1) The risk of performing an inadequate } \\
\text { workout, since there is a great temptation } \\
\text { to be distracted by conversation, etc.; } \\
\text { 2) Lack of control over the correct } \\
\text { implementation and the risk of harming } \\
\text { yourself; } \\
\text { 3) You depend on time from others. }\end{array}$ \\
\hline
\end{tabular}

All options have certain pros and cons. There is no ideal option. However, what is negative for one is not such for another. It is also quite obvious that the choice depends on the priorities of the person. The results of the survey (Figure 2) show that preference is given 
to independent training. Since for people, the ability to independently manage their time is of great importance. You can train in this format at any free time and almost anywhere.

\title{
How do you prefer to play sports?
}

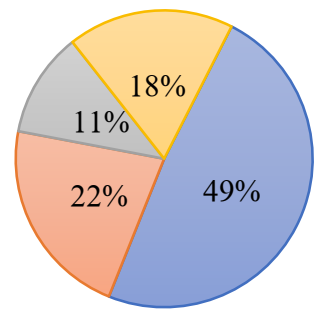

\author{
$\square$ On my own \\ $\square$ Under the supervision of a \\ coach \\ $\square$ Group workout \\ $\square$ In a company (for example, \\ with friends)
}

Fig. 2. How do you prefer to play sports?

The next important point - the form of physical activity - is analyzed in Figure 3.

The most popular are jogging and strength training. Running, dancing and swimming are all cardio workouts, but dancing is less attractive as it is not interesting for everyone. Mostly the dances were chosen by female representatives of different ages. The situation was similar with stretching. The rest of the types of training were approximately equally in demand among men and women.

\section{What physical activities do you prefer?}

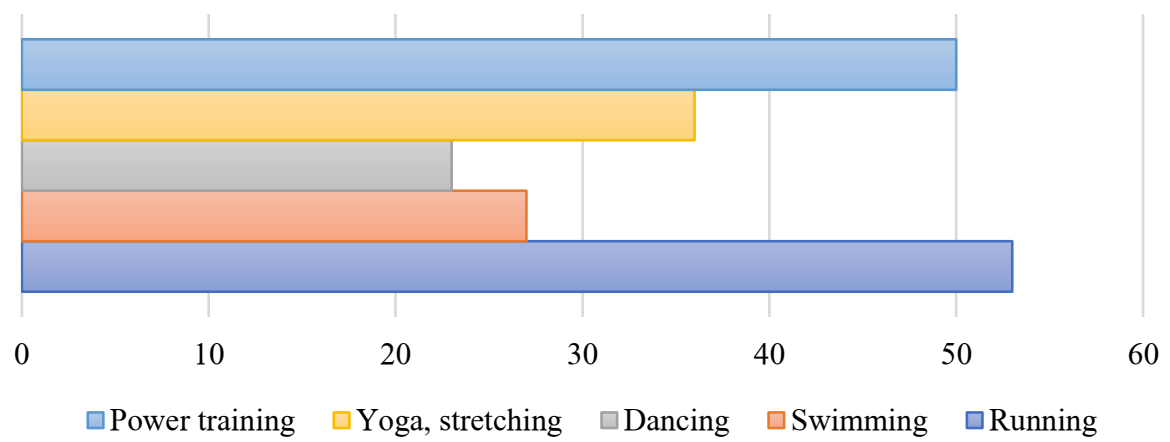

Fig. 3. What physical activities do you prefer?

Cardio training is aimed at developing endurance and improving the functioning of the cardiovascular system, and strength training is aimed at increasing muscle mass and strength. However, this does not mean that with strength training you are not developing your endurance or training your heart muscle. In the course of any workout, a person works to improve and strengthen his body.

Stretching should be given special attention as it is often underestimated. It is stretching training that helps maintain the mobility and elasticity of muscles, tendons and ligaments. Moreover, stretching promotes faster recovery of muscle tissue after intense exercise. For maximum efficiency, all types of loads should be taken into account and combined.

In general, physical activity promotes healthy sleep, improved posture, and self-control. During training, you gain confidence in yourself and your strengths, and hormones are produced that positively affect mood. You train your body and willpower to arrive at your 
improved version. An analysis of what interferes with an active lifestyle is shown in Figure 4.

\section{Why don't you play sports?}

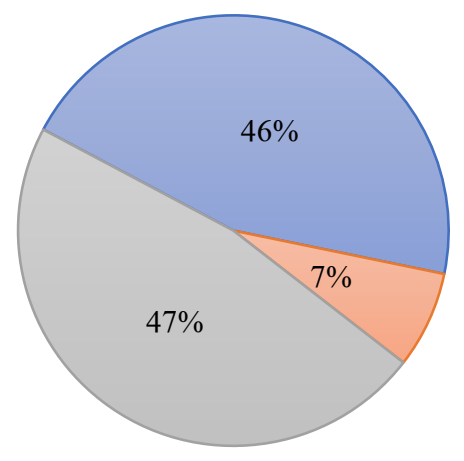

$\square$ Not enough time

$\square$ Lack of desire

$\square$ Laziness

Fig. 4. Why don't you play sports?

One of the most important questions is why people ignore physical activity (Figure 4). According to the survey results, 3 main factors were identified: 1) lack of time, 2) laziness, 3) lack of desire.

Self-discipline and motivation can help cope with laziness. If a person is clearly aware of the importance of physical activity and its impact on the quality of life, then he has a desire to act. In carrying out a specific task, people are mainly goal-oriented. That is why a correctly set goal is the key to success.

If a person does not have enough free time, then independent training is a wonderful way out of this situation. Once again, we note that sports within the framework of a healthy lifestyle differs from professional sports and does not require many hours of daily workload. It takes 15-30 minutes to do a little warm-up, joint gymnastics, take a short run, etc. You also need to understand that physical activity is not only full-fledged training. It also includes walking and climbing stairs. Therefore, the lack of time for training can be compensated by a walk to the place of work or study, or the refusal of the elevator. Even such small details help to improve the condition of the body and develop endurance.

Various IT technologies play a huge role in our life. Therefore, it is not surprising that there are various applications with training programs. The sphere of assistants-controllers of the fulfillment of the norm of physical activity is also developed. A striking example is fitness bracelets. In addition to the usual clock function, they also count the hours of activity, exercise intensity, calorie consumption, remind you to warm up and much more. Also, thanks to the bracelet, you can control the number of steps taken. It has long been said that it is necessary to take $8,000-10,000$ steps per day. This led to the fact that this aspect can be controlled not only with the help of a fitness bracelet, but also with the help of a phone, since there are a huge variety of applications for counting these very steps.

Online training and online marathons have also appeared on the sports market. However, at this stage of time, only $27 \%$ are interested in purchasing this service. Online marathons include not only a training program, but also the support of like-minded people (communication in a general chat). And yet, most of the respondents admit that they do not feel much motivation to purchase training data and marathons.

Survey results: 
1. Almost $70 \%$ of the population leads an active lifestyle, and $30 \%$ do not. The main reasons for giving up physical activity are: laziness $-47 \%$, lack of time $-46 \%$, lack of desire $-7 \%$.

2. People prefer to study at home on their own.

3. The most attractive physical activity options are running and strength training.

4. The fitness industry is developing not only offline, but also on various internet platforms and applications.

\section{Conclusion}

Thus, sport is an integral part of a healthy lifestyle. There are many options for keeping your body in good shape. You just need to choose the ones that suit you best and satisfy your needs. But first, we must define a clear goal for ourselves and understand why we need sports. If we consider sports as a factor that has a positive effect on health, then we can conduct a small experiment: for some time, perform sports exercises (exercises, joint gymnastics, minitraining, etc.) for 15 minutes and monitor your condition. Many people will notice that physical activity has a beneficial effect on their body (for example, it improves sleep and performance).

Not only we ourselves are interested in our health, but also the state. Since a healthy population is a contribution to the future of the country and a major resource. Therefore, various events are held annually aimed at the development of sports culture (for example, the Ski Track of Russia, the All-Russian Half Marathon "ZaBeg.RF" and others). The state finances the construction of new sports grounds and the arrangement of parks and other facilities so that people have the opportunity to spend their time with health benefits.

\section{References}

1. A. Sharma, R. Pal, IRE\&F (2019)

2. C. Azémar, R. Desbordes, I. Wooton, JCE (2020)

3. E. Almiron-Roig, S. Navas-Carretero, J. A. Martinez, SW (2020)

4. G. Rota-Graziosi, JME (2019)

5. J. Bian, X. Zhao, EJOR (2019)

6. J. P. Choi, T. Furusawa, J. Ishikawa, JIE (2020)

7. K. Iwakoshi, S. Tahara, I. Takano, JC (2019)

8. K. Kawachi, H. Ogawa, T. Susa, IRE\&F (2020)

9. M. Brülhart, M. Jametti, JPE (2019)

10. M. Mardan, M. Stimmelmayr, JDE (2020)

11. N. A. Goncharova, N. V. Merzlyakova, IJSCM, 9, 772 (2020)

12. N. V. Zavorohina, N. A. Pankratieva, N. A. Goncharova, FTO: PDMRAI (2019)

13. P. Heimberger, EJOEAO (2021)

14. Ya. Deng, D. You, Ya. Zhang, SP\&C (2021)

15. O. A. Sbitneva, International Journal of Humanities and Natural Sciences (2020) 